\title{
Extension of the distributional range of Lithobius obscurus Meinert (Lithobiidae, Lithobiomorpha) in organic and conventional apple orchards in Central Chile
}

\section{Extensión del rango de distribución de Lithobius obscurus Meinert (Lithobiidae, Lithobiomorpha) en plantación orgánica y convencional de manzanas en Chile central}

\author{
Mario G. Moya-Hernández ${ }^{1,2}$, Emanuel Vega-Román ${ }^{3,4}$, Claudio A. Sáez ${ }^{5,6}$, Enrique A. Mundaca ${ }^{7 *}$ \\ ${ }^{1}$ Instituto de Ciencias Biológicas, Universidad de Talca, 2 Norte 685, Casilla 747, Talca, Chile. \\ ${ }^{2}$ Millennium Nucleus Centre in Molecular Ecology and Evolutionary Applications in Agroecosystems, Instituto de Ciencias \\ Biológicas, Universidad de Talca, 2 Norte 685, Talca. \\ ${ }^{3}$ Departamento de Zoología, Facultad de Ciencias Naturales y Oceanográficas, Universidad de Concepción. Casilla 160-C, \\ Concepción, Chile. \\ ${ }^{4}$ Programa de Magíster en Enseñanza de las Ciencias, Universidad del Bío- Bío, Chillan, Chile. \\ ${ }^{5}$ Environmental Laboratory of Coastal Research, Departamento de Medio Ambiente, Facultad de Ingeniería, Universidad de \\ Playa Ancha, Casilla 34-V, Valparaíso, Chile. \\ ${ }^{6}$ Centro de Estudios Avanzados, Universidad de Playa Ancha, Traslaviña \#450, Viña del Mar, Chile. \\ ${ }^{7}$ Escuela de Agronomía, Facultad de Ciencias Agrarias y Forestales, Universidad Católica del Maule, Casilla 7-D, Curicó, Chile. \\ *emundaca@ucm.cl
}

The species of the order Lithobiomorpha (Miriapoda) are, in terms of size, the smallest members of the class Chilopoda (Edgecombe \& Giribet 2007). Lithobiomorpa can generally be found under stones, rocks, wood and soil litter. All the species belonging to this order are anamorphic, with 15 tergi and a constant number of 15 pairs of legs (Silvestri 1905). At species level, the most common diagnostic characters are their antennae length and number of antennomeres. Species of this order also show a varying number of ocelli.

The first records of the species of the order Lithobiomorpha for Chile were documented by the naturalist Claudio Gay (Gervais 1847), who described two species of this order: Henicops chilensis and Lithobius platensis. Subsequent research carried out by Silvestri $(1899,1905,1909)$, Porter (1912) and Chamberlin (1955) added seventeen new species to the Chilean record. The most recent record of Litobiomorpha for Chile is the new species Paralamyctes welingtonensis Edgecombe, 2003 (type locality of Torres del Paine National Park, Chile).

The species Lithobius obscurus Meinert, 1872 (Lithobiidae, Lithobiomorpha, Chilopoda) was first described under the name of Chilebius coquimbo (Chamberlin, 1955), in the type locality of Coquimbo, Chile (29 $\left.58^{\prime} 40.11^{\prime \prime S}-71^{\circ} 20^{\prime} 18.01^{\prime \prime O}\right)$. The main diagnostic characters of L. obscurus are antennae with 28 to 30 segments; three rows of ocelli located on each side of the cephalic plate; surface of tergites 9 to 13 rough. Coxal pores $5,5,5,4$ to $5,6,6,5$ varying from circular to transverse in shape.

The aim of this short communication is to expand the distributional range of the species Lithobius obscurus Meinert, 1872 (Chilopoda, Lithobiomorpha) and to discuss the importance of agricultural areas as a suitable habitat for this species.

Specimens were collected in apple orchards located in Los Niches, in the Curicó Province, in the Maule region, central Chile. Study areas consisted of four apple 'Granny Smith' orchards with organic $\left(35^{\circ} 2^{\prime} 13.68^{\prime \prime} \mathrm{S} ; 71^{\circ} 10^{\prime} 56.24\right.$ "O) and

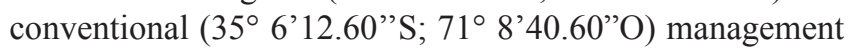
(Fig 1.). Specimens were collected by locating 20 non-baited pitfall traps within each orchard (80 traps in total), at least 15 meters away from the border to minimise the edge effect. Trapping sessions were carried out once a month, weather allowing, during the months of April, September, November (2012) and January (2013). Collected specimens were preserved in $70 \%$ alcohol vials (Saiz et al. 2000) and taken to the laboratory to be photographed and determined under the stereomicroscope (Figs. 2A-C). Species identification was carried out based on research published on the topic by Chamberlin (1955) and Mundel (1990). We recorded 36 specimens of adults of $L$. obscurus. 
In general, relatively little is known of the Chilean myriapod fauna, particularly in regards to life cycles and distribution of native species. Although in this study the collecting effort was restricted only to specific localities, these results represent a significant expansion of the original distributional range of $L$. obscurus reported by Chamberlin (1955). Furthermore, we consider it likely that this species had inhabited the area before the establishment of the artificial crops, although further studies are required to understand how this species uses modified habitats.

Finally, within the context of the global scenario of biodiversity loss due to dramatic human-caused changes in land use, the findings of this study contribute to highlight the role played by farmlands in sheltering native biota in central Chile.
Voucher specimens were deposited at the Museo de Zoología, museum code MZUC-UCCC41792, Universidad de Concepción (MZUC), Concepción. Chile.

Material examined. Four males, 3 females, $30^{\text {th }}$ of April 2012. Three females, $10^{\text {th }}$ of September 2012. Four males, $6^{\text {th }}$ of November 2012. One male, $7^{\text {th }}$ of January 2013 (35 $6^{\prime}$ ' $12.60^{\prime \prime}$ S- $\left.71^{\circ} 8^{\prime} 40.60^{\prime \prime} \mathrm{W}\right)$. One male, $6^{\text {th }}$ of November 2012. One male, $7^{\text {th }}$ of January $2013\left(35^{\circ} 1\right.$ ' $42.42^{\prime \prime}$ S- $71^{\circ} 11^{\prime} 47.69^{\prime \prime}$ W). Collected in conventional apple orchard, Los Niches, El Maule Region, CHILE, M.G. Moya coll. Two males, $10^{\text {th }}$ of September 2012. Six males, 5 females, $7^{\text {th }}$ of January

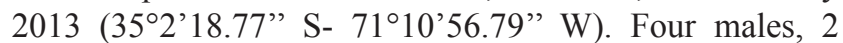
females $7^{\text {th }}$ of January $2013\left(35^{\circ} 6\right.$ ' $12.60^{\prime \prime}$ S- $\left.71^{\circ} 8^{\prime} 40.60^{\prime \prime}\right)$. Collected in organic apple orchard, Los Niches, El Maule Region, CHILE. M.G. Moya coll.

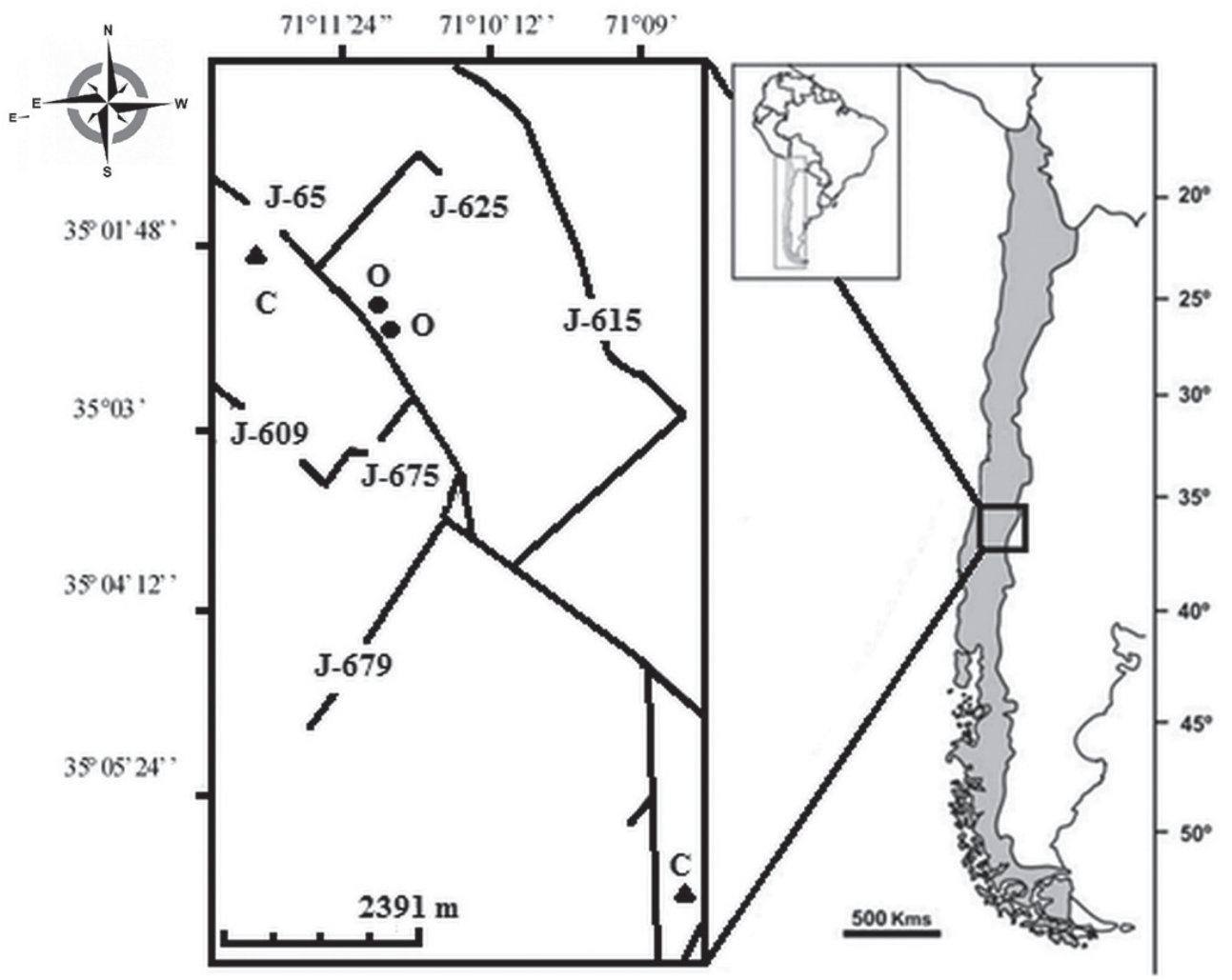

FIGURE 1. Location of the sampling sites in conventional (C) and organic (O) apple. Orchards were located in Los Niches, Curicó province of El Maule Region, central Chile. J-numbers represent secondary local roads.

FIgURA 1. Ubicación de los sitios de muestreo en plantaciones de manzanas convencional (C) y orgánica (O). Las plantaciones están localizadas en Los Niches, provincia de Curicó, Región del Maule en Chile central. La letra J-número, representan caminos secundarios cercanos al área de estudio. 

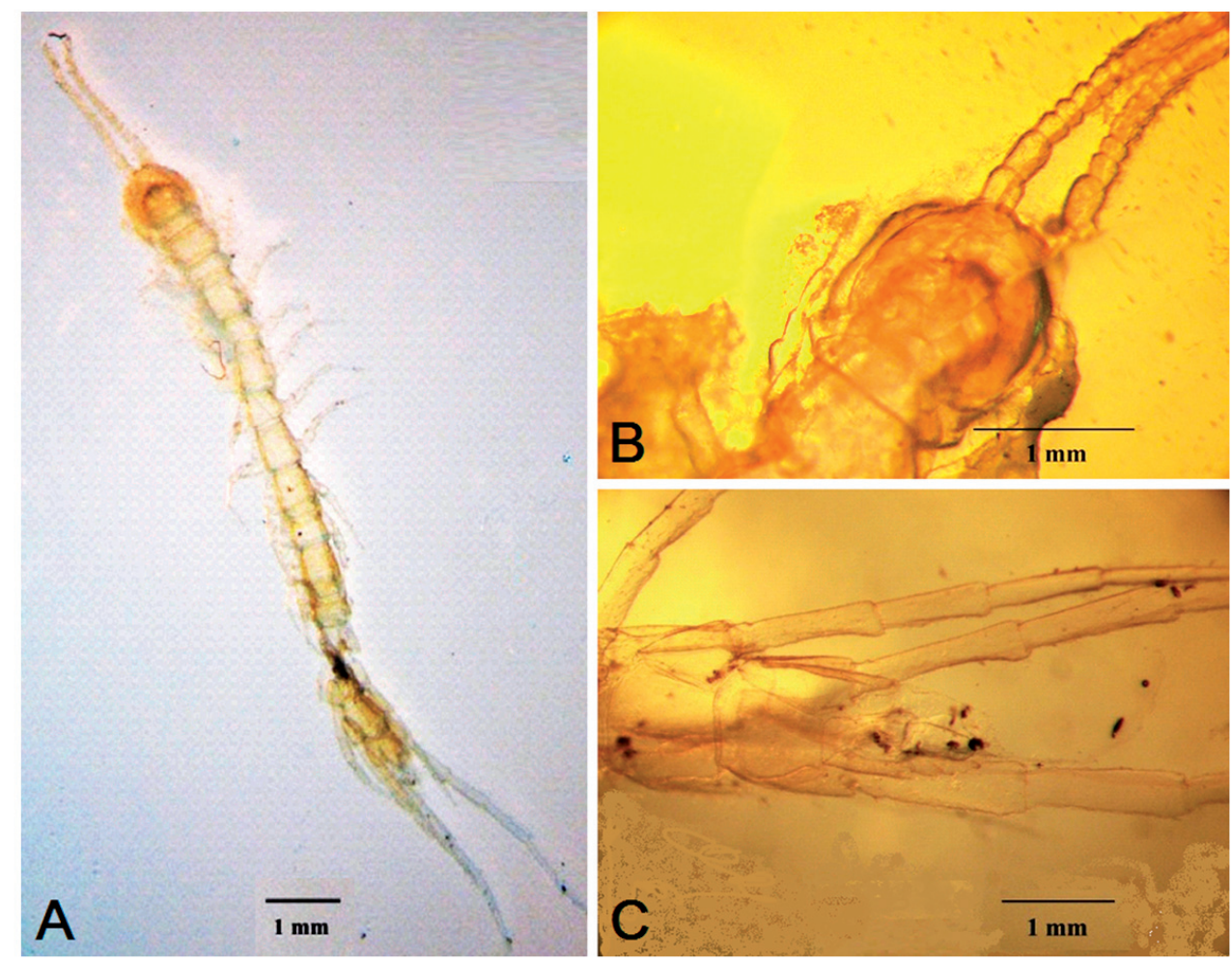

FIGURE 2. Lithobius obscurus Meinert, 1872 (Chilopoda, Lithobiomorpha). (A) Dorsal view of a specimen of $L$. obscurus. (B) Dorsal view of the antennae, head, forcipules. (C) Dorsal view of the rear end, showing the last pair of sensorial appendixes and gonopods. Length of scale bars $(\mathrm{A}),(\mathrm{B})$ and $(\mathrm{C})=1 \mathrm{~mm}$.

Figura 2. Lithobius obscurus Meinert, 1872 (Chilopoda, Lithobiomorpha). (A) Vista dorsal de un espécimen de L. obscurus. (B) Vista dorsal de las antenas, cabeza, forcípulas. (C) Vista dorsal de la porción terminal del cuerpo, mostrando el último par de apéndices sensoriales y gonopodios. Longitud de las barras de escala (A), (B) y (C) $=1 \mathrm{~mm}$.

\section{ACKNOWLEDGEMENTS}

We would like to thank Mr Felipe Torti and Mr Andrés Chávez from SURFRUT Ltd. for allowing us to enter the apple orchards. To Ciro Campos for his help in the field and Dr Mariana Lazzaro-Salazar for proofreading this article. To Dr María Eugenia Casanueva for providing the infrastructure to conduct this research and Dr Mylenko Aguilera, from the Departament de Zoología - Universidad de Concepción, for helping us take the photographs.

\section{BIBLIOGRAPHY}

Chamberlin, R. 1955. Reports of the Lund University Chile Expedition 1948-1949. The Chilopoda of the Lund University and California Academy of Science Expeditions. Acta Universitatis Lundensis N.S. 215:1-44.

Edgecombe, G.D. 2003. A new species of Paralamyctes (Chilopoda: Lithobiomorpha: Henicopidae) from Southern Chile. Zootaxa 193:1-12.
Edgecombe, G.D. \& Giribet, G. 2007. Evolutionary Biology of Centipedes (Myriapoda: Chilopoda). The Annual Review of Entomology 52:151-70.

Gervais, P. 1847. Miriápodos. In: Historia Física y Política de Chile, Zoología, Tomo Cuatro (Ed. Gay, C.), pp. 53-72. Paris, en casa del autor. Chile, en el Museo de Historia Natural de Santiago.

Mundel, P. 1990. Chilopoda. In: Soil Biology guide (Ed. Dindal, D. L.), pp. 819-832. John Wiley \& Sons, New York.

Porter, C. 1912. Introducción al estudio de los miriápodos. Catálogo de las especies chilenas. Boletín del Museo Nacional de Historia Natural 4:16-68.

Saiz, F., Yates, L., Nuñez, C., Daza, M., VAras, M. \& Vivar, C. 2000. Biodiversidad del complejo de artrópodos asociados al follaje de la vegetación del norte de Chile, II región. Revista Chilena de Historia Natural 73(4):671-692.

Silvestri, F. 1899. Contribución al estudio de los quilópodos chilenos. Revista Chilena de Historia Natural 3:141-152.

Silvestri, F. 1905. Myriapoda. In: Fauna Chilensis (Ed. Plate, L.), pp. 715-769. Dritter Nand, Gustav Fischer Verlag, Jena.

Silvestri, F. 1909. Nuevo genere di Henicopidae (Chilopoda). Revista Chilena de Historia Natural 13:211-212.

Recibido: 05.07.14

Aceptado: 15.06.15 